\title{
参加と協働のまちづくりに向けた支援主体としての保健婦に関する考察 STUDY ON PUBLIC HEALTH NURSE AS SUPPORTER IN COMMUNITY MAKING BY PARTICIPATION AND PARTNERSHIP
}

\author{
倉原宗 孝* \\ Munetaka KURAHARA
}

\begin{abstract}
The purpose of this paper is to study on Public Health Nurse that facilitate community making by participation and partnership. I carried out a questionnaire survey that correspond to Public Heal th Nurse everyone of Hokkaido from a view point of community making. As a result, a Public Health Nurse have a strong interest for community making, but that the interest is not done sufficient with a jab. I understood that other sorts of occupations and besides that have scarcely comprehension and recognition to a Public Helth Nurse. And the coordinator who coordinates the work of public health nurse and other works is necessary, and so on.
\end{abstract}

Keywords: community making, Public Health Nurse, participation, life, まちづくり， 保健婦，参加，生活,

\section{1. 背景と目的}

今日、ハードとソフトの統合概念としてのまちづくりを進めてい く上で、住民各人・各主体の個性と主体性を如何に見出し高めてい くか、また住民・行政・企業等の各主体の協働関係を如何に育てて いくかが模索・実践されている。そこでは、従来の専門家・事業主 体優位による計画行為を越えて、行政・尃門家等が地域コミュニテ イに身をおきながら、住民との協働関係の中でハード・ソフトに渡 る暮らしの質と意義を計画に結実させていくこと、また住民自身も 自らの住環境に対する関心と認識を高めつつ行動主体・計画主体と して地域・地区のまちづくりに関わっていくことが求めらる。

ところで、こうしたまちづくりを展開していく上で、本稿ではそ の支援主体としての「保健婦」、及び「保健婦業務」に着目したい。 そこには、取り扱われる対象や内容に、また方法論として、さらに 関わる者の持つべき態度として、今日とこれからのまちづくりを展 開していく際に多くの意義・意味があると思うからである。

生活者・ユーザー参加が問われる今日のまちづくりではあるが、 行政と住民、制度・事業と生活・暮らしの間には未だ厚い壁が存在 する。こうした障壁を低くするためには、まちづくりに関わる専門 家・事業サイドにとって、地域・地区や生活者のきめ細かい情報を すくい上げることは重要である。それに対して、住民・生活・地域
にフィールドを持つ保健婦は、より良き住まい・暮らしづくりに向 けて地域・生活者に潜在する声をもすくいあげる職能を持つのでは ないか。一方、こうした職能は、地域・住民サイドに対しても、行 政や制度・事業についての理解と認識を深めることへ寄与し得るの ではないか。現実の問題はあるものの保健婦は、その職業的立場か ら、住民と行政、住民と住民、行政内部の関係を柔らかく結びつつ、 互いの立場・役割を相互に活かした協働のまちづくりに向かう上で 多くの示唆と可能性㘧む存在ではないだろうか。

また、現代社会の持つ問題・課題は複雑・多様であるが、それら を総合的に乗り越えていくための一つの鍵は、「地域」や「生活」 に着目することである。多様な価值観や感情をもともなった生々し いまちづくりの問題や関係を解読するためには、地域・生活という スケールと文脈の中で状況を読み解く「生活主義」「現場主義」の 視点が重要になるが ${ }^{1}$ 、そのための方向と力法を、地域、また一人 一人の生活をフィールドにする保健婦は示唆し得るのではないか。 さらに、ヒト・クラシ・イノチといった視点に重きをおくその職 種は、人の営み・生活を総体的に見る姿勢と方法を示し得る。合理 性・効率性の追求優位に組み上げられた現代社会システムの中では、 都市や暮らしの諸要素はバラバラに分断され捉えられてきた傾向が ある。しかし本来、暮らしや住睘境は、人と人、人と睘境の多様な 
つながりの中で形成・生成しているものである。今日の機械論的・ 要素還元論的な思考と方法の色濃さに抗い、暮らしや住環境をホリ スティックに捉えること22、人と人、人と環境の多様なつながりを 大事にした「関係主義」のもとに開かれる思考と方法、視点と態度 が求められている。その中で、ヒト・クラシ・イノチの視点から取 り組まれる保健婦業務には、これからのまちづくりを進める上で学 ぶベき、人と人、人と環境の関係を柔らかく紡ぎ、暮らし・住環境 を総体的に改善・創造していく態度と術が示され得るのではないか。

一方、参加と協働のまちづくりを展開していく際こうした保健婦 及び保健婦業務の意義は大きいと思うものの、しかし現実には多様 な問題や課題も存在する。また、都市計画・まちづくりの分野では、 その職種に対する認識は低い状況があると思われる。そこで本稿で は、参加と協働によるこれからのまちづくりを展開していく上で、 その支援主体のひとつとして、「保健婦」という職種にみる意義。 可能性、現状・課題を明らかにし、保健婦分野から見たあるいは保 健分野を包含したまちづくりの方向と方法を探ることを目的とする。

\section{2. 研究の染組みと方法}

\section{1 研究方法}

上記目的を掲げた上で、本稿ではまず保健婦に関する文献を通じ て、その職種をまちづくりの視点からいくつか読み解いておきたい ( 3 章)。一般的に保健婦業務に対する認識は低く、またそれは建築 ・都市計画分野においてもいえると思うが、そのことが筆者のヒヤ リングでもうかがえた互いの分野のまちづくり展開の障壁になって いると思うからである。加えてこうした保健婦業務の背景に、今日 とこれからのまちづくりを展開していく上で共有すべき又示唆され る点があるからである。

次に、全道の保健婦を対象に行ったアンケート調査をもとに、保 健婦やその専門家へのヒヤリング等も加えながら、まちづくりにお ける保健婦業務の現状・課題・可能性を、また保健婦とともに各分 野・各主体も含めた今後のまちづくり展開の方向と方法を探る ( 4 章)。

ところで、まちづくりと一言でいっても、それの指す内容は建筑 ・都市計画分野をはじめ健康・福祉など各分野で多様である。ここ では特に断らない限り、まちづくりと記す場合は建築・都市計画分 野で今日一般的に使われているものとし、住民参加によりあるいは 住民・行政・専門家等の協働を目指しながら、「物的環境の改善と 目には見えない生活面の向上を同時に考えていく活動」としたい ${ }^{3)}$ 。 また分野や内容を限定・強調する際は、その都度断ることとする。

\section{2 保健螮及び保伐螮拝務の概要}

\section{ここで保健婦及び保健婦業務の概要を見ておきたい。}

保健婦とは、「厚生大臣の免許を受けて、保健婦の名称を用いて、 保健指導に従事することを業とする女子をいう」 ${ }^{4)}$ とされる。その 免許取得の為には、一般的に看護学校 (3年)を卒業後さらに 1 年間の 保健婦学校卒業が必要となる。その数は全国 31,581 人(平成 8 年 12 月, 看護婦 (士) ·准看護婦 (土)の数は928,896人)で、保健婦一人あたりが 対応する住民数は、各自治体で差はあるが約 5 千 5 百人にものぼる ${ }^{5)}$ 。 その業務内容は一般的に、乳幼览の検診、予防接種、成人・高齢 者の健康相談・管理、家庭訪問、といったことが思いつくが、保健 婦の活動内容と課題についてまとめられた資料によると、保健婦活 動の主な機能として、(1)実態把握（地域診断）機能、(2)計画策定・
評価機能、(3)相談・支援機能、(4)教育・普及啓発機能、(5)調整・ネ ットワーク化機能、6システム化・施策化機能、の6つを上げてい $る^{6)}$ 。こうした活動内容の近年の傾向・課題として、直接的なサ一 ビス提供の実施とともに、関係機関との連携や調整、また計画立案 のための活動の割合が高くなってきていることが上げられている。

また保健婦の所属先は、主に市町村、保健所、本庁の 3 つがあり、 各所属先で先の機能の具体的内容や配分は異なる。本庁組織の目的 は直接的なサービス提供ではなく、全体的レベルでの調整、事業化、 施策化を行う。保健所保健婦は、専門機関等の協力を得て広域的に 健康問題を把握し、先駆的事業の実施と普及を図り、また市町村等 へ情報提供や技術支援を行う。市町村保健婦は、住民の身近な相談 者として関係者と協働し、住民の相談に応じ、また保健事業を地域 の関係者との連携のもとに企画・実施する。本稿で対象とする保健 婦は主にこの市町村保健婦で、その数は全保健婦の約半数に当たる。

\section{3. まちつ゚くりに向けて保健婦が共有・示唆する視点}

まず、保健婦の誕生やその活動内容について、まちづくりの視点 からいくつか読み解く。そこには、異分野に思われがちな建築・都 市計画分野のまちづくりと保健婦分野に共通の背景、またこれから のまちづくりを拓いていく上での示唆的視点・態度が読みとれる。 主に文献・雑誌 $(1) \sim(10)$ 、及び、保健婦分野専門家（高等看護学 校・行政保健婦等) へのヒヤリングと各印刷物による。

\section{1 保健婦誕生の背景と活動方法}

「保健婦活動の発端はイギリスのウイリアム・ラスボーンによる リバプールでの貧しい病人への組織的な訪問看護活動の立ち上げと 19世紀中頃、同じイギリスでの睘境衛生の改善、家族の健康教育・ 保健指導等に重点をおいた高い教育を受けた女性による活動があげ られている」7。すなわち18世紀後半から19世紀にかけての産業革 命に伴い、労働力として吸収された都市の人口膨張から生じた極め て悪質な環境衛生の改善の中で保健婦活動は生まれた。

ところで、近代都市計画の流れを振り返る中でも、同じ18～19世 紀にかけての公衆衛生の問題は重要な位置づけを持つ。そこでは健 全な住居・住環境を獲得するための実践と成果が生まれており「公 衆衛生法(1848年)」「労働者住居法(1851年)」等も成立しているが、 同様な社会的・時代的背景のもとに保健婦が誕生していることを認 識しておく必要があると思う。

またこうした誕生の背景とともに、互いの分野における「教育・ 指導」という方法論にも共通性がある。先の引用にも記されている が、保健婦活動は健康教育・保健指導に重点が置かれている。一方、 住まい・まちづくりを見据える際、「居住者の住意識向上による住 宅管理」という点から、同時代のオクタビア・ヒルは、「物が悪い からこそ”人”に着目する」という方法を切り開き、人々の住まい方 に対する教育・指導を実践していった ${ }^{8)}$ 。

筆者のヒヤリングまた後のアンケートなどから、今日の都市計画 分野と保健婦分野に関わる者がそれぞれ乘離していることが問題と して指摘されているが、こうしてみると互いの分野が共有し合う点 は大きいと思う。とともに、教育・指導という方法論と実践には、 今日の参加のまちづくりに対する示唆が時代を越えて李まれている。 3.2 まちづくりに向かうスタンス

今日のまちづくりを進める上で、関わる専門家・プランナーは、 
計画実行後の調查や地区外からの評価のみではなく、地域や住民の 内部に入り、思考と行動を住民・ユーザーと共にしつつ課題や問題 解決の方法を探り出していくことが重要とされる。コミュニティや 生活についての認識と共感を深めていくためにも、対象地区・地域 に専門家・プランナーが身を向けることは、今日のまちづくりで必 須の条件ともいえるが、我が国において看護の立場から地域に最初 に入っていったのが保健婦業務である。

イギリスのDistrict Nursing(地域において家庭にいる病人に対す る訪問看護)、アメリカのVisiting Nursingの存在に対して、明治後 半、生江孝之が、日本には組織的に在宅患者の家庭訪問看護を行う 事業が存在しないことを指摘した上で説いた「巡回看護婦事業」は大 正期になり実践される ${ }^{9}$ 。それは今日においても「家庭訪問」とし て保健婦業務の重要な内容として脈々と実践され続けている ${ }^{10)}$ 。

そうした業務内容に対し、保健分野専門家へのヒヤリングでは、 「保健婦は家の中へ入れる唯一の存在（訪問という権限）、住民の 体に触れる存在」であることが指摘された。そこには、住民の健康 状態にもよろうが、単なる権限を越えて、心身の共感ともなう信頼 に支えられた住民と保健婦の関係が見える。また、そうした存在ゆ えに保健婦は、後に見る生活者の極めてきめ細かな情報や状況をす くい取っている存在であるといえる。

このことは、住民・行政間に未だ厚い壁がある今日において、地 域の情報・潜在的要求をもすくいあげる上で、また住民・行政間を 結ぶ媒介者として、さらにまちづくりの尃門家・プランナーの持つ ベきスタンスとして、重要な示唆と可能性を持っているように思う。 3.3 保健婦業務に見るまちづくりプランナーに共有する態度・存在 保健婦業務はこのように地域や生活に入っていく中で、患者とし ての一対象から、個人あるいは社会そのものを対象にすることへも 向かう。先の巡回事業の保健分野における意義として、「医療に関 する技術が、単に患者である個人を対象としてのみ用いられるので はなく、社会生活を営んでいる個人、もしくは社会そのものを対象 として活用されたという点」 ${ }^{11}$ の指摘がある。また、こうした訪問 の際必要なのは看護や育児の知識にもまして「社会事業領域での知 識と技術であった」こと、それはけしろソーシャルワーカー的な

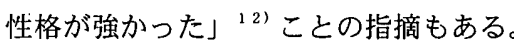

例えば、大正後期の巡回看護事業については、13もの多様な職務 内容を掲げた上で、患者・生活者の全ての状態・環境を見つめ取り 扱うような「態度」の必要性が強く語られている ${ }^{13)}$ 。昭和初期の朝 日公衆衛生訪問婦協会の保良せきも「住民の持つあらゆる健康上の 問題に関する教育をなすのが保健婦であり、訪問看護を含めた総合 的な活動であるのが当然であると主張する」 ${ }^{14)}$

また保健婦は、専門家と生活者、技術と暮らしを結ぶ媒介者とし ての存在意義も大きい。例えば明治期終わり頃の様子に、（家庭の 事情までは知らない）医者の立場からは当然の患者に対する指示も、 （絶対安静と云われても働かなければ生きていけない）患者は往々 にして守ることは出来ないが、それに対し保健婦は、生活環境全体 を対象にして適切な忠告を与える存在であることが記されている(5)。 そのことは今日においても「住民にとって医師とは違い、保健婦は 身近な存在として感じていたであろう」ことが指摘されている ${ }^{16)}$ 。

今日のまちづくりに関わる専門家・プランナーは、専門分野と生 活の双方の用語・知識・技術を使い分けられること、使いこなせる
ことが要求されると思うが、相互の媒介者としての保健婦の存在、 及びその姿勢と技術には共有すべき点が大きい。

また保健婦が当時から、住民の総合的健康向上のためには外的処 置だけではなく、自ら健康や暮らしについて関心・認識を高めてい く住民の主体性の意義・可能性を認識している点も重要である ${ }^{17) 。 ~}$ まちづくり・住睘境整備において住民・ユーザーが、自らの住環境 に対して如何に関心 ・認識を高め能動的・主体的に関わっていくか

は重要な課題であるが、保健婦分野と共有する視点として大きい。

世界保健機関 (WHO) は、その憲章において、健康の概念を身体的の みならず、精神的、社会的なものに広げた。続くアルマ・アタ宣言 （1978）では、「人々がまず最初に出会う基本的な保健・医療サービス であるプライマリ・ヘルス・ケアを重視」し、そこでは「地域共同体 の個人と家族に、彼らの全面的な参加を通じて‥」と住民参加の重 要性を強調した ${ }^{18)}$ 。さらに1986年オタワ憲章では、健康に対して、 身体・精神的、社会的、政治・経済的に暮らしを取り巻くトータル な環境から考える「ヘルスプロモーション」の概念を提示し、その 実現の上で「住民参加」は最も重要な方法の一つとされている ${ }^{19)}$ 。 健康に対するこうした動きは保健婦活動にも大きく波及している。 とりわけヘルスプロモーションの概念に基づく「住民参加」方法が 全国的に模索・実践されている ${ }^{20)}$ 。その中で、地域住民の健康実現 に向けて幅広い分野の様々な条件が整っていく為の展開方法を「地域

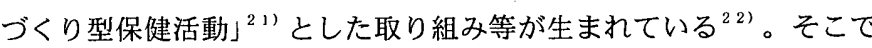
は、ハード・ソフトにわたる計画対象の総合性、住民参加等の方法 ・技術、参加の中で住民の主体性を育てる重要性、ファシリテータ 一・コーディネーターとしての保健婦の役割等が培われつつある。

健康というソフトな領域から発しつつハードも含めたトータルな 生活環境を対象にした保健婦分野のこうした活動には、空間・ハー ドから発しつつトータルな生活環境を計画対象にしている建築・都 市計画分野のまちづくりと、概念、方法・実践、主体の役割など重 なり共有し合う点が多い。勿論、互いの分野の独自の役割は認識・ 重視しなければならないが、一方で、相互の分野の認識・方法・フ イールドの共有とその中での示唆は、今日とこれからのまちづくり を展開していく上で大きな必要性と可能性を持っていると思われる。

\section{4. まちづくりに対する保健婦の現状・課題・可能性 一北海道内の保健婦へのアンケート調查よりー}

上記の視点・意義を踏まえた上で、まちづくりに向けた保健婦の 現状・課題・可能性を探るためのアンケート調查を行った。アンケ 一ト対象は全道の市町村保健婦 (今回は職務内容の違いから (上記2. 2)、保健所及び本庁保健婦は主に除いている，212市町村，1，379人） である。実施機関は1999. 1 3月。各市町村に対して、アンケート の窓口としてふさわしい課・係を関係者よりアドバイスいただき郵 送。各市町村担当者でとりまとめていただき返送してもらった。

有効回収数・率は、135市町村 (63.7\%)、755通 (54.9\%)である （回答者の世代構成は、20代-326人 (43.2\%)，30代-219人 (29.0\%)，40 代-145人 (19.2\%)，50代-51 人 (6.8\%)，60代- 1 人 (0.1\%), 不明-13人(1. $7 \%)$ ）。アンケート内容がまちづくりと保健婦業務に関してかなり踏 み込んだものであり、記述式が多かったこと、また各保健婦の業務 内容の多忙さなどを考えると、返送されたものは貴重な情報であり、 
また充分に有効な考察が出来ると考える(考察でも見るように返送さ由記述の枠を設けた(図 4, 8)。

れた記述内容や添付された手紙にもそのことはうかがえる)。また、

町村によっては業務・私事の事情で担当者が代表して回答している ものもある(3 町村)。設問は次の内容である ${ }^{23)}$ 。

1. まちづくりへの関心の度合い(選択式)

上記関心が仕事の中でどのくらい実現できているか (選択式)

2. 保健婦業務とまちづくりの関係の度合い(選択式)

3. まちづくりに関して経験してきた業務内容 (選択、記述式)

4. 上記業務に関わった際の喜び・苦労、疑問・暮藤 (記述式)

5. どんなまちづくりをしたいか(記述式)

6. 上記の際の問題・䜋題(記述式)

7. その他、自由な意見 (記述式)

及び、年䶣・職務年效・所属など

以下、各設問内容にそって、結果と考察を述べていく(アンケート には極めて詳細な示唆的記述が多くされていた。その細部を提示。 考察したいが、本稿では紙幅の都合上割愛する)。

\section{1 保涟螮のきちつ゚くりへの闒心。实現の店合い(設問1, 2)}

まちづくりに対して保健婦は、皆が大きな関心を持っているよう だ(図 1)。これは町の規模・世代構成に関係なく、全市町村で関心 はある(65.8\%)」「非常に関心がある (32.2\%)」がほとんどで、「あま り関心はない」は極めて少なく、皆が強い関心を持っている。

一方、そうした関心を仕事の中で実現できているかについては、 多くが満足していないようだ(図 2)。「ほとんど出来ていない(33.5

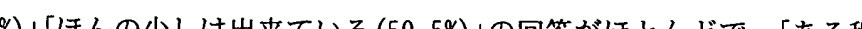
度出来ている」十分出来ている」は少ない。この傾向は特に若い世代 に多いようである。そこには、後の設問にもみるが、様々な制約(時 間·財源・人等)や課題の大きさ・難しさ(住民·行政の意識辟発、心身 共に健康な人やまちづくりの大切さ・難しさ、期間もかかる等)がある。

仕事 (保健婦業務) とまちづくりは関係あると思うかについては(図 3)、「大いに関係ある」「る程度関係ある」とほとんど全ての人が関 係の強さを示している。建築・都市計画の立場からのアンケート調 㚗であったが、健康・保健の立場からもまちづくりという幅広い対 象へ関わることへの認識の強さが再確認された。また、保健婦とし てとともに行政職員として当然のことといった声も多かった。これ らの傾向は、若い世代よりも年齢の高い世代の方が強いようにもう かがえた(50代一大いに関係ある84.3\%，関係ある15.7\%，20代一大い に関係ある $63.8 \%$ ，関係ある $35.0 \%) 。$

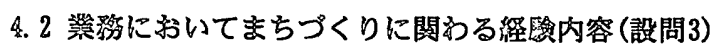

次に、まちづくりに関して、これまでの仕事の中でどのようなこ とに関与してきたかを尋ねた。設問にあたり、取り扱うまちづくり について可能な限り説明をしてはいるものの ${ }^{24)}$ 、具体的内容が想起 しづらい面があると思われた。そこで保健婦関連の専門家からのア ドバイスのもと回答を容易にするために、まずこちらから 7 つ項 目を設定し選択してもらい、その選択した項目に対し具体的内容を 記述してもらった。さらに項目にあてはまらないもの等に対して自

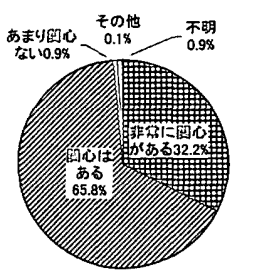

图1 まちつくりに対する

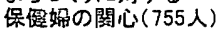

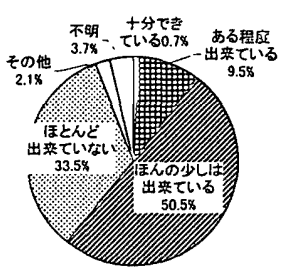

2 まちづくりへの閣心の管務に おける实現度合い(755人)

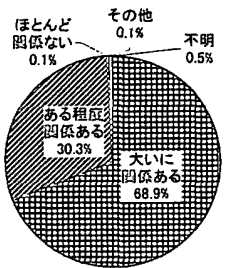

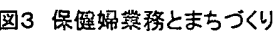
の閶係の深さは(755人)
選択数は計1，764であった。まずこちらから設定した 7 項目とそれ ぞれの選択数・割合 $\left(1,764\right.$ の選択に対し)を図 4 に示す ${ }^{25)}$ 。住民を 対象にした学習会(2))が職業がら多く、次に祭りやイベント等 (6))、 地域や生活等の情報収集・発信(1) が選ばれている。これらに対し て施設・空間・住宅への設計関与 (3)、都市計画・まちづくりに関 する事業や計画づくり(4) は共に10\%程度である。

次に、具体的内容が記述されているものを全てすくい上げると1, 322あり、それらから項目を設定し再整理すると図5のようになった。 最も多いのがAの学習会・講演会・研修会等で、職業がら健康・福 祉・育児に関するものが多かったが、その中でテーマ・内容にまち づくりに関することが直接掲げられているもの（高龄者社会に対応 したまちづくり学習、障害者も住みよいまちとは、住民とまちづく りについての夢や意見交換, 等) が41記述、住宅に関するもの（改 造等）は 5 記述であった。次いでD・イベントに関する記述が多い。 Bの住宅・施設・空間への関与は119記述であり、主に保健センタ 一、高齢者・障害者住宅、その他公共施設、あるいは公共、一般住 宅を対象に設計への助言・アドバイスを与えている。また、Cのま ちづくりに関する計画への関わりは、57記述となっており、主に総 合計画・住宅マスタープランなどが記されている。

ところでこれらの数值について、現段階の情報のみでは正確な読 みとりをしかねるが、後に続く設問における保健婦の声が計画・設 計に反映しづらい等の記述内容も含めると、この設問への回答者数 601 人（1，322記述）に対して、建築・都市計画関係（B，C）への 関わりが少ないように感じる。とりわけCにおいては、幅広い分野 ・主体の声を計画に反映させるためにも保健婦が関わる空口がより 広くなることが期待されるように思う。後の設問においても、行政 ・専門家を含め他分野の人たち、とりわけ建築・都市計画サイド等 からの保健婦の意見や情報を反映させるような空口が十分開かれて いないことへの不満、情報交換・連携の必要性が多く記されていた。 一方、設計者・担当者が自分達（保健婦）の意見を設計・計画に反

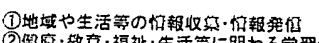

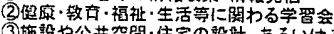

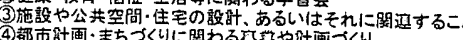
(5)㮩自のテーママでサークル活叻 自祭りやイベンド (8) その地

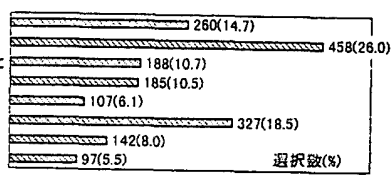

図4 設定項目の選択にみるまちづくりに関する保健婦の業務内容, 1,764 選択

A. 学習会・的演会・研供会等

B，住宅·能般・空間への閣わり

C. まちつくりに閶する旪画への䦎わり D. イヘンント

\section{E. 枯報笔但}

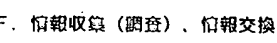

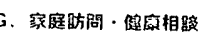

4. 链展に时する叶画つくり

その他の活助

图5記述にみるまちつくりに関する保健㛿の業務経験内容. 1,322記述 
映してくれたことについての記述もいくつか見られたが、それに対 しては高い評価と効果について記されていた。

$\mathrm{E}$ ・情報発信が77記述 (5.8\%)、F・情報収集・交換が96記述 (7. 3 \%) となっている。おそらく健康・育児等に直接関わることは広報紙 などを通じてかなりされていると思うが、地域へのアクションを仕 掛けるような情報の発信・収集の仕方が今後重要になるのではなか ろうか。その上で、Dのイベント等を活用した中で、健康・保健の 楽しく新鮮な情報の発信・収集も今後多く考えられよう。

G. Hは業務として当然のことであり、まちづくりへの捉え方が わかりづらかったためと思われ、回答に迷われた方が記述したりし なかったりした結果だと思う。本来もっと大きな值に成るであろう。

\section{3 喜びや苦労、暮藤ややりがい (設問4)}

設問 3 や普段の保健婦業務に関わる中で思う喜びや苦労、疑問や やりがい等について、自由に記述してもらった。519人の方から関連 する記述 (記述内容の種類毎に見ると574の意見)をいただいた。記述 内容は大きく3つのタイプになる。一つは喜び・やりがいについて、 二つめに苦労・難しさ・悩み・葛藤といったこと、三つめに自分自 身が感じたり知ったりしたことへの感想などである (図 6 )。

記述内容中 255 意見 $(44.4 \%)$ と約半分が喜びややりがいについての ものだった。一方、苦労・難しさ・悩み・葛藤についても271 (47.2 \%)の意見があった。それぞれの内容を図 7 , 図 8 に示す。また、仕 事を通じて、あるいは自分自身が新たに知ったこと感じたことに対 する記述もあった (48意見)。主に、住民参加・住民主体の取り組み の遅れや、一方で住民の持つ力の大きさについて、障害者の立場に 立った際の町の住みづらさ、保健婦が住民の声を聞く立場にあるこ と、まちづくりに関与できていること、職務の影響や効果について の感想などである。以下、各内容を見ていく。

職業がら当然のことではあろうが、住民の健康面の改善・向上と ともに彼らの意識や行動に変化が見られたことが喜びの記述として 多かった (図 7, (1))。また、保健婦の存在・職種に対する他者(とく に住民)からの共感が大きな喜びになっている(同，(5))。こうした住 民と直に接する経験ゆえの率直な声であろう、住民の声を聞くこと の大切さが多く記されていた。また、住民とともに計画や空間に具 体的な成果を与えたことが貴重な喜びとしても記されている(同, (2))。 喜びの声と共に苦労や難しさの声も同じくらい語られていたが、 こうした喜びと難しさは常に表裏の関係で各保健婦の胸にあるよう だ。後の問題や課題にもみるが、専門職として、また組織として以 上に個人の考え・行動が影響する職務ゆえの自分自身に対する悩み が多い (図 8, (3))。とりわけ若い世代の保健婦に、仕事をどう展開し ていけばよいのか問答している姿が強いようである。

よく言われるが、縦割り行政機構の弊害として他のセクションと の連携が悪いこと、また他職種の理解・認識の低さへの指摘も見ら れた(図 8,(2)(4))。一方、その中でも、様々な職種・部署と協働した 経験の中で難しさと共に良さ・効果の生き生きとした記述もあった (図 7，(3)。また、安易な業者任せのスタイルを越えて、苦労は伴う ものの、自らの手で協働していくことから生まれる多面的効果 (実効 性の高さ、後の他部局との連携、充実感・達成感等)も記されていた。

こうした協働の経験は建築・都市計画分野にも成果をもたらして いた(使い勝手の良い住宅、施設・空間形成など)。それは地域・住 民に対して良い効果を生むと共に、保健婦自身の喜びや優れた経験
にもなっていることが記されていた。また、建築・住宅サイドでは 気づきづらい、ユーザー・生活者の状況・状態をすくい上げる声も みられた（例えば、修理・改造しても、その間にユーザーの健康状態 ・病状が悪化すると結果として使えないこと、経済的な理由やスペ 一スの問題、借家、アパートのため許可なく改修できないなど)。

後にも見るが、保健婦の職業的位置づけの不明確さ、他の課・職 種からの理解の低さ、あるいは上司の理解が得られないこと等も多 くの保健婦が記している。

一方、こうした喜びや苦労、悩みや課題をともないながら現実に 直面する問題は大きいものの、新しい経験の積み重ねの中で自らの やりがいある仕事として前向きに見つめるバイタリティあふれる声 も若い保健婦に多く見られた。

\section{4 保健婦が望むまちやまちづくりのあり方(設問5)}

まちづくりを展開していく上で、それぞれの分野の目標とするま ちづくりのイメージを知る必要がある。そこで次に、保健婦達はど のようなまちづくりをしたいと思っているかを尋ねた ${ }^{26)}$ 。531人の 方から1,003の内容の記述があった。内容を大きく分けると、町のイ メージや目標に対する記述 (440意見)、まちづくりに向けた住民・行 政など各人・各主体の姿勢や関係について (284意見)、まちづくりの 切りロ・方法について (225意見)であった。次の問題・課題と重複す る面もあり、ここではその概要を見てみる。

町のイメージや目標について、「活気のある町」「生き生きとした町」 という表現の記述が多く、その中でも職業柄か福祉・健康・安全等、 をテーマにしたものが多かった (298意見)。その主な内容を見てみる と、直接、健康を強調している記述 (73意見)、地域の福祉や安全の あり方について(例えば、弱者に優しい、安心して生活できる等, 14 4意見)、互いに声を掛け合ったり助け合う等の相互扶助の関係をい ったもの (63意見)、子どもや育児に関する事 (18意見)等であった。

ハード面に対する理想や提案もあり(85意見)、その中ではとりわ け障害者や弱者に優しいまちのための記述が多かった(60意見)。特 に、ユーザー・生活者のための細部に渡る具体的要求・提案がされ ていたことが目に付いた。ボランティア・人材を育成することを目 指した意見もあった (46意見)。また、各町の特性についての記述(例 えば、坂が多いので $\cdots$, 面積が広いので...等, 19意見)等もあった。 まちづくりに向けた各人・各主体の姿勢や関係については、行政 と住民が協力してまちづくりを進めていくことに対する記述が最も 多かった(101意見)。また、他の職種・専門家と協力して行うまちづ くりの記述もあった(37意見)。あるいは地域のみんなでといった表

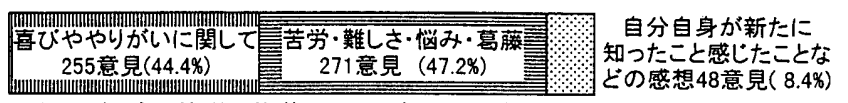

図6 喜びや苦労、葛藤ややりがいに関する保健婦の記述タイプ （519人,574意見）
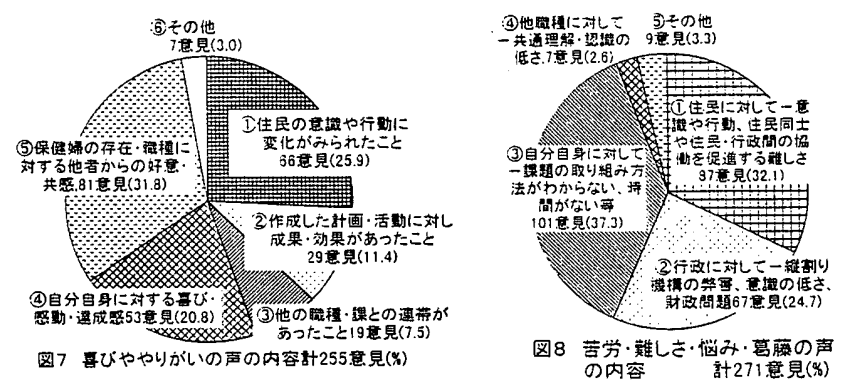
現 (38意見)、弱者と共に (10意見)等も見られた。地域における様々 な人の存在と彼らの想い、一方、行政内部の事、と多様な立場・状 況にある人達の存在を知る故だろうか、互いの立場・役割を客観的 に見つめた上で「んなで」取り組んでいくことへの希望が多かった。

各主体毎に対しては、住民に対する理想(住民が主体的意識を持っ て行う…等, 43意見)、行政に対する理想(特に行政内部のまちづく りへの姿勢を変えること, 12 意見)、また、若者が重要・必要等の記 述（13意見)があった。保健婦が(…するような)や保健婦と住民が (‥していくような) といった保健婦の瞕業を強くふまえた記述もあ った(31意見)。

まちづくりを進める上での具体的提案の記述も多かった。方法と して、福祉 (30意見)や健康づくり (13意見)から取り組んでいくこと の内容、また住民参加の仕組みについての提案 (35意見)、あるいは ハード提案 (27) 等があった。また、より具体的提案として、情報交 換やグループ同士の交流、理想の町やまちづくりについて語り合う 等の「場」や「機会」をつくることが望まれている(58意見)。その中に は、学校開放など、地域特性・社会的背景を踏まえたものもあった。

保健婦としての自分の職業的立場を強く意識した提案も多かった (87意見)。まちづくりに向けた保健事業・業務の拡大、住民参加や 住民意見をより活かすことの提案、まちづくりのための場や機会、

体制づくりについての提案が多かった。

\section{5 問題队㹎題（設問6）}

既存情報からうかがえる保健婦分野の状況を確認するとともに、 異分野からは見えづらい問題や課題、あるいは示唆をすくい上げる ために、上記のようなまちづくりを進める際に、あるいは現在、ど のような問題や㹎題があるかを尋ねた。全部で468人の方から 9420 内容の記述があった。その内容を大きく分けると、(1)住民・行政等 まちづくりを進める際の各主体に関すること(375意見)、(2)まちづく り・住民参加を進める方法・仕組みに関すること(66意見)、それと (3)保健婦自身または保健婦業務に関すること(501意見)が上げられる。

まちづくりを進める上での各主体に関する意見の内容を見てみよ う（図 9）。まず、住民に対するものがあったが(109意見)、その多 くは住環境やまちづくりに対して如何にして関心を持たせるか、主 体的意識をつくっていくかの課題である。一方、こうした住民に関 する課題以上に、行政主体に関する問題・課題が多く記されていた (140意見)。その内容は主に行政内部の意識や姿勢について (77意見)、 行政の縦割り機構の問題 (63意見)に関する二つである。

また、こうした住民と行政の関係についての課題 (57意見)もあつ た。主に、㹎題の共有、協働していく姿勢、行政が住民の意見をも っと聞く姿勢の必要性などである。住民に対しても、また行政内部 に対しても、まちづくりに向かう認識と主体的意識を育てていくこ とが課題となっている。そのためにもまず、情報の公開性、またそ うした情報共有を通じて地域が向かうべきイメージの各人・各主体 間での共有が要求されよう。

高齡者・障害者など弱者に関する問題・課題も上げられていたが、 弱者から見たハード・ソフトにわたる問題・課題とともに、高齢者 が高齢者を介護している現状や、単なる優遇措置ではなく高齢者。 弱者自身の自律に関することも見られた。また若者がもっと積極的 にまちづくりに関わることを課題として上げているものもあった。 まちづくり・住民参加を進める方法や仕組みに関する意見は、幾
つか細かい内容にわたった。主なものに、住民・行政など各人・各 主体の互いの共通イメージ・目標づくり(11意見)、組織やシステム づくり (10意見)、住民同士のネットワーク（9 意見）、住民同士、住 民と行政の対話の場・環境づくり (8 意見)が示されていた。

また、期間や財源などに制約のある一つの事業から持続的・面的 まちづくりへ展開することの難しさ (4 意見)、状況を総合的・客観 的に把握・評価する必要性 ( 4 意見)、その他に敬蒙・啓発、町外者 との交流、参加者の年齢差、等が上げられていた。

各保健婦自身また保健婦業務に関わることを強く意識しながら示 された意見として図10のような内容があうた。他・多職種の理解。 連携がとれないことが多い。そのことは施設やハード分野に対する 問題指摘にもつながっていた。関連して、保健婦という職種の内容 ・職業的位置づけが明確でないこと、あるいは住民・他分野の人の 理解が低いことの指摘がある。職務内容がある意味で広く、それゆ え不明確にも見えること、また住民と極めて密着する一方で行政職 という立場にあること、といった表裏の内容を合わせ持つ保健婦の 声として記されていた。そこには効果・成果が短期に表れづらいと いう職務内容の難しさも記されていた。

こうした問題とともに、異分野間の共同体験 ${ }^{27}$ の必要性・効果も 多く記されていた。互いの立場・役割を認識しつつ、かつ創造して いく為には、単に情報伝達・交換のみではなく、各人・各分野間で の共同体験が重要だと思う。こうした異分野間を結んだ体験的活動 の中で生まれる新しい発見・感動が、様々な問題・悩みを抱えつつ も㹎題を解き明かす鍵と前に進もうとする力を与えている様子が生 き生きと記述されているものもあった。

こうした悩みとともに、技術職として個人的業務が多い為であろ うか、直面する状況に対し各保健婦から、自分自身が問題・办不足 であるといった真摰な声も多く記されていた。その中で、保健婦業 務を進めるために各人の状態を総合的に把握し業務の方向を示すス 一パーバイザーの必要性も記されている。保健婦業務をより効果的 にまちづくりに反映するための行政内部におけるポストの必要性も 数は少ないが記されていた ${ }^{28)}$ 。

また、先にも触れたが、保健婦としての職業的立場をより意識し た上で住民のまちづくり意識をどう高めていくか、あるいは健康。 健康づくりに対する住民の理解を如何につくるかの課題も上げられ ている。住民・行政双方にわたり人を育てることも課題として多く 上げられている。リーダーがいないこと、住民のマンパワー・ボラ ンティア不足、人材育成の強化等である。

その地域・まちならではの問題についての声もあった。例えば、 大都市周辺の町において、自分達の町の実状・良さには目を向けず どうしても住民が大都市同様のサービースを要求する、広大な酪農 地帯を持つ町、あるいは坂道の多い町などで、送迎や弱者の自由な
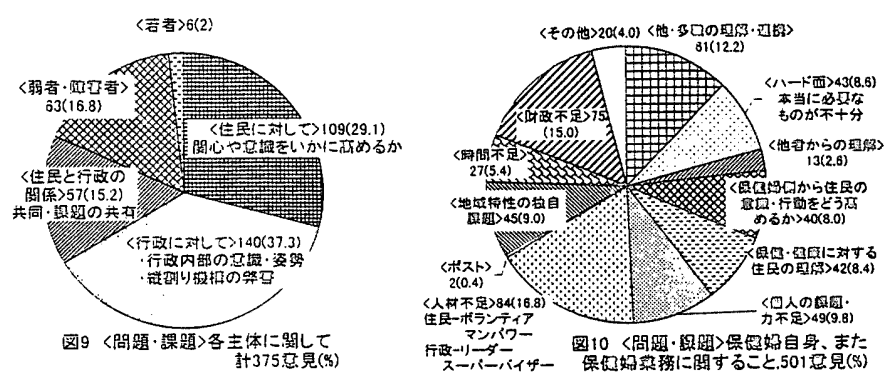
移動手段がそしいなど、地域と生活の細部を知る保健婦ゆえの声が あった。また、財政上の問題、時間不足の指摘も多く見られた。

\section{6 その他の意見や感想(設問7)}

その他の意見・感想の中にも貴重な示唆があった。その中で、ア ンケートが難しかった、記述式の質問が多かったことへの指摘等が ある(45人)。幅広い情報や意見を得るために、あえてハード・ソフ トにわたる「まちづくり」のテーマで質問を投げかけたこと、また筆 者自身の保健婦・保健婦業務に対する認識が浅かった点から来てい る面もあるかと思う。今回のアンケート調査は、建築・都市計画分 野からまちづくりに関する保健婦の意識や認識、業務の実態を把握 する初めての作業でもあると思われ、今後、互いの協働体験などを 通じて知識・経験・認識の共有に向かいたい。

一方、保健婦業務とは一見別の分野（筆者ら建築・都市計画）か らのアンケートの投げかけに対する強い共感・喜びの声も見られた (32人)。それはアンケートの結果や内容に関わらず、建築・都市計 画分野から保健婦分野に視点が向けられたこと、アンケート実施自 体に対するもので、先の課題等にも見たように保健婦達が求めてい たことのようである。健康・保健分野と建築・都市計画分野との関 係に限らず、より良き住環境・生活環境を築こうとする目標を共有 する多様な分野からの、また各分野への、互いの積極的アプローチ が今後求められるであろうし、そのことが互いの分野の向上へも向 かうと思う (その他、貴重な意見・提案があったがここでは割愛する)

ところで、保健婦と共に仕事をした経験を持つ都市計画プランナ 一等 ${ }^{29)}$ へもヒヤリングを行ったが、まず共通していたのが、保健婦 の立場はもちろん、その職種内容に対する知識・認識の浅さであっ た。その中で実際に保健婦と接し、その知識・能力の高さ、とりわ け地域や住民に対する情報の広さと深さに意外な驚きが示された。 そこでは、生の声を背景にした（実態を伴った）意見・情報の提供 者としての保健婦の重要性が語られている。

しかし、こうした保健婦の存在、またその情報を活かすためのネ ットワークやコーディネーターの不在が指摘されている。その中で、 保健婦の存在をまちづくりに当初から引つ張り上げるシステムの必 要性、また、きめ細かい使い勝手を示し得るアドバイザー、様々な 住民の立場（高齢者・障害者・主婦・子ども等）からの代弁者とし て、施設の計画・設計に際してはなるべく早い段階から保健婦のチ エックが入るシステムを作ること等が指摘された。

\section{5.まとめ}

本稿では、今日とこれからのまちづくりを展開していく上で、保 健婦及び保健婦業務に着目し、その現状・課題・可能性をみてきた。 まず、一般的にあまり認識されていないと思われる保健婦及びその 職務内容だが、保健婦誕生の背景、生活者に対する教育・指導とい う活動方法、地域や生活を大切なフィールドにしていること、健康 を切りロにしつつトータルな住環境・社会睘境を対象にしているこ と、生活者一人一人の主体性の重視など、これからのまちづくりを 進める上で、また専門家の持つべき態度として、共有・示唆される 点が大きいことを示した。

こうした保健婦の現状・課題・可能性として、アンケート・ヒヤ リング等を通じて次のようなことをみてきた。保健婦は、地域・地 区や生活者一人一人の非常に細部にわたる実態をともなった情報を
持っている。これは建築・都市計画分野のまちづくりにおいても極 めて貴重なものである。また、まちづくりに対しては強い関心を持 ち、住民一人一人のハード・ソフトにわたる健やかな暮らしを願つ ており、そのことが保健婦自身のやり甲斐や生き甲斐になっている。 技術的な面からも生活者一人一人の立場に立ったハード・ソフトへ のアドバイザーとしての能力を持つ。こうした保健婦は、住民と行 政、生活と制度・技術を結ぶまちづくりの支援主体として大きな可 能性を持っていると言えよう。

一方、業務の現状においては、住環境やまちづくりに対して如何 に住民の意識や行動を高めていくか、住民と行政の関係をどう結ん で行くべきか、また行政内部の意識や姿勢、縦割り機構の弊害等が 指摘された。これらは、建築・都市計画分野をはじめ多分野間で共 有しなければならない課題である。しかし、こうした課題の共有の 上で、また先の能力や資質を活かす上でも、保健婦に対する他分野 の理解・認識が低いことが問題として示された。

これらに対して、今後、異分野間での共同・協働体験を伴うよう な認識の共有が求められる。アンケートにも、そうした経験が、実 効性高い成果、後の他部局との連携、充実感・達成感に䋈がること が示されていたし、保健婦が求めていることである。建築・都市計 画サイドのまちづくりは、こうした体験の場・機会になるであろう し、保健婦分野は勿論、積極的に異分野への㥶口を開いていきたい。 さらに、保健婦業務を総合的に見つめられる視点、保健婦の存在 や情報を活かす為のネットワークやコーデネーターの不在が問題 として掲げられているが、こうした共同・協㗢活動の中でそれぞれ の職務の位置づけが見えてくる面もあると思われる。また、とりわ け若い保健婦に自らの課題にどう取り組むかの悩みが大きかったが、 こうした体験の場は自らの職務内容の確認と創造に向かうのではな いか。その中で各保健婦の独自の個性・能力が顕在化・生成してい くことが期待される。そのことは関わる他の職種も触発するだろう。

謝辞 : 非常に多仙な中、アンケートにご協力いただいた保健婦の皆さんに深く 感謝したい。とりわけ共感と励ましの声は非常に嬉しかった。帯広高等看護学 院保健学科の諸先生方をはじめ保健婦分野の各専門家の方には貴重なアドバイ スをいただいた。アンケート作成・郵送・回収にあたり、行政担当各氏には非 常に丁寧に対応・協力いただいた。情報整理にあたり田中宏実氏(当時北大)、 道工大研究室各氏に協力いただいた。皆に感謝したい。なお本研究において北 海道ノーマライゼーション研究センターの助成（H. 10）を受けたことを記す。 参考文嗝

（1）大国美智子，保健婦の歴史，医学書院，1973

（2）小栗史朗・木下安子・内堀千代子, 保健婦の步みと公衆衛生の歴史, 医学 書院, 1985

(3) 岩永敏博, 地域づくり型保健活動のすすめ, 医学書院, 1995

(4) 岩永·黒田·和田, 地域づくり型保健活動の手引き, 医学書院、1996

（5）日野秀逸，保健活動の歩み一人間・社会・健康，医学書院，1995

(6)ペンダーヘルスプロモーション看萝論, ノラ・J・ペンダー, 小西恵美子

監訳，日本看荠協会出版会，1997

(7)保健の科学, 保煡学会研究会編集, 杏林書院,

（8）地域保健，地域保健研究会編集室

(9)生活教育, 保健同人者

(10)延藤安弘，ハウジング序説，新建策学大系14ハウジング，彰国社，1985 㭪注

1）まちづくりを進める上で、「生活主義」「現場主義」の重要性が今日説か れてきている。例えば、延藤安弘，創造的住まいづくり・まちづくり，岩浪 書店，1984など。また筆者らも既報でそのことを示した。住民主体のまちづ くりに向けての北海道ミ二独立国の活動に関する考察，建築学会計画系論文 報告集, 1996.10, pp. 165-175

2）今日、関わり（relationship）に焦点をあてた〔ホリスティック」なアプ ローチがまちづくりをはじめ多様な分野で重視されてきている。例えば、シ ヨン・P・ミラー著，吉田・中川・手塚訳，ホリスティック教育一いのちの 
つながりを求めて一，春秋社, 1994. 等

3) 延藤安弘, まちづくり読本, 晶文社, 1990, p. 10

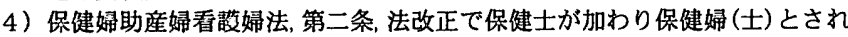
るが、現在、保健士效は檑めて少なく、本稿では便宜上「保健婦」として取り扱う。 5)これからの地域保健における保健婦（士）の活動指針，保健婦（士）活動

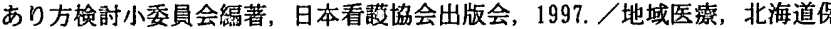
健福祉部地域医索䛾, 平成 8 年度による。

6) 平成 8 年度厚生科学研究，これからの行政組織における保健婦活動のあり 方に閣する研究，代表 : 湯澤布矢子/平成 9 年度厚生科学研究，同 II，各幾 能の内容を簡単に記すと以下のようである。

(1)実態把挃（地域唁所）機能一家庭訪問，健康相談・教育等を通じて個別的 な馆報収焦、関連分野の墇報及び調㸖・研究を総合し、支援を必要とする住 民の把握と地域の煡康問題を総合的に判断。

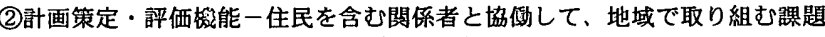
を明らかにし事業計画の策定、及びその評価。

(3)相談・支援杼能一生活上の图難や不自由さを抱える住民の声を受け止め相 談に応じ、本人・家族が主体的に㹎題解決できるように支援する。

(4)教育・普及啓発娺能一予防的視点に立ち、健康の維持・增進及び住民の主 体的社会参加の锶点から、計画的に健康教育や広報活動を行う。

(5)調擎・ネットワーク化檄能一保健の分野にとどまらず、関係職種及び閶係 蕧䦕との連絡・連墒のもとに総合的な調整を図る。

6)システム化・施策化譏能一保健事業並びにサービス全体が、円滑に提供さ れるために、包括的なシステムを償築し、設備やマンパワー等の体制の整備 を図るとともに地域保健対策の方針を決定する。

7 ）金川克子, 地域看臀之保健婦（士）活動, 参考文献 (7) 中の1999，v01. 41 p. 4 /参考文献 (4), pp. 162-164

8）参考文献 (10)pp. 28-33/我が国ではF・ナイチンゲールは標めて著名だが 英においては彼女と○・ヒルを19世紀英国の社会生活改善に貢献した代表的人 物として位圈づけている。ナイチンゲール(1820-1910)が看蒜の分野、またヒ ル(1839-1912)が住宅管理という、どちらかというと女性的職種が 2 人の女性 から誕生していることは興味樑い(同文献)。さらに、ナイチンゲールも将来の 睵程を考える際、看落の分野か、そうでなければ教育の分野を希望していた （神谷美恵子，生きがいについて，みすず書房, 1980, pp. 30-31）ことも興味深い。

9) 参考文献 (1) pp. 1-2

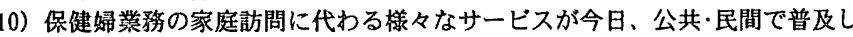
てきた。その為、以前よりは業務における家庭訪問の割合は小さくなってい るとされる。しかしそれでも，全業務における家庭訪問にかける時間の割合 を見ると(平成 9 年度），22項目に及ぶ職務内容中最も大きく、市町村で $11 \%$ 强 (人口規模で異なる)，政令市·特別区では17.8\%になる。さらに従来家庭訪問 にも含まれていたであろう指導·相談·管理など住民と直接接する内容の業務 含むと、市町村·政令市·特別区で約 $60 \sim 65 \%$ になる(平成 9 年度保健婦

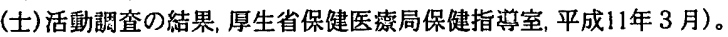

11) 参考文献 (1) D. 6

12) 参考文献 (1) p. 25

13）当時の巡回看陆における任務として、家庭施問，患者の手当、妊産婦·助産·授

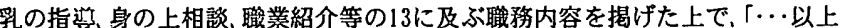
は少し筑囲が広すぎるやうであり、・当然の任務ではありませんが、先方の云 い分なれば、何でも彼でも善く聞く、聞いて出来ることなら何でもして上げる と云う䄇神と態度でなければ,真から取り合うようにならぬのでありますから ・少々いった保健婦の「態度」について記されている。参考文献 (1)，p.14

14) 参考文献 (1)p. 138

15) 参考文献 (1) p. 54

16) 参考文献 (2) 木下, p. 90

17）例えば、1960年代の保垏婦業務を記す記述の中に、「…病気は䔩と注射だ けではなおらないこと、肉体自身のなおる力をたすけるために正しい看譔が 大切であることなどを話しながら、氷枕のあて方や喚起のしかたなどを実演 ・指道すると、母たちはみなれないことにどぎまぎしながらも、一生㬎命に 閉いてくれ、やってくれる。‥」と、患者（生活者）の能動的意識・行動を 高めている様子と意義・効果が示されている。参考文献 (2) 杢下, p. 126

18）参考文献 (4)pp. 211-216

19) 参考文献 (3)p. 32、及び (6)pp. 13-14

20）例えば、住民参加を促した活動，これからの地域保健における保健婦（士） 活動指針，保健婦 (土)活動あり方検討小委員会編著，日本看設協会出版会， 1997. 5 , pp. $22-26$

21) 参考文献 (3)

22）例えば文献 (4)で紹介されている千葉県八千代市，静岡県竜洋町等では、 保徤計画づくりに際し、地域住民と共に「警らしの理想の姿」を考えること が行われている。そこでは健康・福祉・子育て等ソフト面とともに、図書館 等の施設、散歩する安全な場所といった空間へも目を向けたハード・ソフト のトータルな住環境のあり方が模索・桡等されている。また、こうした取り 组みにおいて従来、専門家（保健烀）主耑だったのに対して、住民一人一人 の自発的行動の高まりや能力が顕在化していったこと、計画策定とともにそ れを実現していく上で、専門家（保健婦）と住民の協恸のあり方や互いの役 割などを認識していったこと、また実現すべき状況を段階的に具体的に表現 していく方法など、参加のまちづくりのあり方と共有する点が多い。
23）アンケートにあたり、主題とするまちづくりに対する認識や捉え方が十分 共有できていない面が現状ではあると思われた。その中で、ここで意図する まちづくりについて理解を示す保健婦関係の専門家（簕者のまちづくりに閣す る講演参加者、時間をかけてまちづくりについて議諭した方等)からのアドバ イスをいただくなど、主旨・内容説明については極力努めた。しかしこちら から設定したもののみでは十分な回答が得られていない面もあるかもしれな い(例えば設問 3 の選択項目など)。一方、こうした状況故に保健婦が抱くま ちづくりの認識・活動内容を把握することに本研究の意義があると思うし、 設問内容とともに方法においても選択と記述式を合わせるなどの工夫をした。 アンケート内容は以下である（紙蝠の都合で部分的に省略，※部分）

I .「まちづくり」といったことへのご閶心の程を教えて下さい。ここでのまち づくりとは…（※上記、説明内容）‥いずれかに○を。

1. 非常に関心がある，2. 関心はある，3.あまり関心はない，4.その他（） I-1. 上記で1. 2. 又は4.に○をつけられた方へ

そうした関心を実際のお仕事の中で何らかの形で実現できているでしょう か(いずれかに○を)。

1 十分出来ている，2.ある程度出来ている，3.ほんの少しは出来ている， 4. ほとんど出来ていない，5. その他（）

II. あなたのお仕事 (保健婦業務) と「まちづくり」は閣係あると思われますか。 1. 大いに閶係ある, 2. ある程度関係ある, 3. ほとんど関係ない, 4. その他( ） III.「まちづくり」ということに関して、これまでのお仕事の中でどのようなこ とに閔与してこられましたか。こちらから考えつくものを1〜7に揚げてみ ました。該当するものの番号にいくつでも○をつけた上で、その具体的テーマ や内容を教えて下さい。

(※本文図 4 の 1 7 の項目を提示し、選択・記述要求)

8. その他…上記に掲げられていない内容が多いかと思います。自由に教え て下さい。(記述要求)

（※この設問而では、選択した各内容に対してく取り組み形態〉等も尋ねている） IV. 上記IIIで閣わられた際の喜びや苦労、葛藤ややりがい等について自由にお 書き下さい。(記述要求)

$\mathrm{V}$ ，あなたの関わられている町で、どのようなまちづくりをやりたいと思われ ますか、どのようなことをやったらよいと思われますか。自由にお書き下 さい。(記述要求)

VI. 上記Vの際に、問題や浬題になると思われることについて教えて下さい。 (記述要求)

VII. その他、お考えやご意見などありましたら、何でもかまいませんからご自 由にお書き下さい。(記述要求)

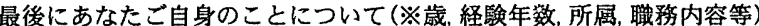

24）アンケートの設問中での説明とともに、別途詳しいお願いと説明を添付し た。その中で、ここでのまちづくりとは、ハードな施設・道路を作るだけで なく、住民の健康・福祉・教育・コミュニティ形成などのソフトな生活をも 視野に入れたもの、保健婦業務䦥係では「地域づくり」といつた言葉・概念 で使われているかもしれないこと、等としている。

25）なお、この設問においては、「住民参加」の程度を偨る目的で、選択した項 目について「取り組みの形態」を尋ねている。本文では割爱するが、参考にポ イントを示すと、項目中(3)施設・空間への設計閣与、(4)計画づくりへの閣与 についてはく行政·専門家内部で行った〉ものが多く、選択数 188 (3)), 185 (4)) 中、それぞれ(3)58.0\%、(4)56.8\%であった。一方、〈一部地域住民も一緒に〉(3)21 5\%, (4) $36.4 \%$ )や〈住民全体を対象に〉(34.8\%, (4)10.3\%)は少ない。他の項目で は、住民を対象にした取り組み形態がより多く見られ、健康・保健分野にお ける設計や計画に対する住民の参加のあり方が今後求められると思う。

26）こうした設問の意図とともに、今回のアンケートでは、地域や住民、蓄ら しやまちづくりに対して保健婦がもつ姿勢や態度についても探ることを目的 にしている。そこには 3 章でも触れているこれからのまちづくりに関わる専 門家のあり方として共有すべき示唆があると考えたからである。その為、設 問4(苦労·喜び等)、設問5(理想のまち・まちづくり)、設問7 (問題·課題) 等を設 定するとともに多くを記述式で求めた。

27）本稿では「協㨽」と「共同」の 2 つの言葉を使っている。どちらかという と「協豞」の場合は、立場・考え・価值観等が異なる個人や主体が協力関係 にあること、またその中で各々にとって創造的変革が期待されるといった二 ユアンスを込め、一方「共同」の場合は、なんらかの効果・成黑も期待する が、まず場や体験を共にするといった意味で使っている。

28）このことはアンケートの記述には少なかったが、保健婦や尃門家へのヒヤ リング・共同作業の際よく聞かれた。その背景に、保健㧹のほとんどが女性 であることに対し社会的にはまだ女性の職業的立場が確保されていないこと （直接ポストのことについては記されていないが、女性の社会的立場の弱さ についてはアンケートにも記述はかなりあった）、一方で保健乖自身が、個 人的な技術職ゆえに、また現在の職務内容を大事にしているゆえに、（ある いは保健婦になる人がどちらかというと皆控えめな性笿ゆえにといった声も あった）、染先してポストを猚得しようとしない、等の二面の声が聞かれた。 29）対象者は，40代男性 2 名、30代女性 1 名である。いずれも建筑系大学を卒業後、

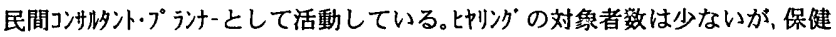

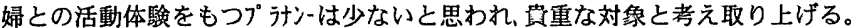

(1999年6月 7 日原稿受理, 2000 年 3 月 21 日採用決定) 